\section{Economic Growth and \\ Environmental degradation nexus in Sri Lanka}

Sri Lanka Journal of Social Sciences and Humanities Volume 1 Issue 2, August 2021: 135-145 ISSN: 2773 692X (Online), 27736911 (Print) Copyright: (C) 2021 The Author(s)

Published by Faculty of Social Sciences and Languages, Sabaragamuwa University of Sri Lanka Website: https://www.sab.ac.lk/sljssh DOI: http://doi.org/10.4038/sljssh.v1i2.45

\author{
Alabi, M.K. ${ }^{1,{ }^{*}}$ Ojuolape, M.A. ${ }^{1}$ and Yaqoob, J. ${ }^{2}$ \\ ${ }^{1}$ Department of Economics, University of Ilorin, Ilorin, P.M.B 1515, Nigeria. \\ 2 Department of Business Administration and Management, Oyo State College of Agriculture and Technology, Igboora, \\ Nigeria.
}

Received: 23 January, 2020, Revised: 28 February, 2021, Accepted: 30 March, 2021.

How to Cite this Article: Alabi, M.K., Ojuolape, M.A. and Yaqoob, J. (2021). Economic Growth and Environmental degradation nexus in Sri Lanka. Sri Lanka Journal of Social Sciences and Humanities, 1(2), 135-145.

\begin{abstract}
The environmental Kuznet curve (EKC) hypothesis suggests that at the initial stage of development, as the economy grows, environmental degradation rises until a turning point is reached whereby the pollution and degradation begins to decline while the economy continues to grow (it follows an inverted U curve). Is the environmental Kuznet curve (EKC) hypothesis applicable to Sri Lanka? What factors are responsible for environmental degradation in Sri Lanka? This study seeks to provide answers to these fundamental questions. Sri Lanka is one of the emerging economies in South Asia with an average annual growth rate of $4.16 \%$ in the last five years and the industrial sector contributing $25 \%$ of Gross Domestic Product (GDP). This hypothesis is tested for Sri Lanka. This study also investigated the major factors behind environmental pollution and degradation in Sri Lanka. Annual data from 1971-2014 was used in estimating the relationship between economic growth and environmental degradation. Carbon (CO2) emission was used as a proxy for environmental degradation while real per capita income was used as a proxy for growth along with other explanatory variables. An autoregressive distributed lag model was used. Results showed that neither the EKC hypothesis nor the pollution haven hypothesis are applicable to Sri Lanka. Long term estimates revealed that increasing energy consumption leads to increasing $\mathrm{CO} 2$ emissions. Secondly, it was observed that energy consumption, urbanization, trade openness, tourism and financial development are among the key factors responsible for the quality of the environment. The policy implication is that the Sri Lankan Government, in conjunction with the private sector must adopt energy saving and environmental friendly technologies and production processes in order to save the environment.
\end{abstract}

Keywords: Carbon emission, Energy consumption, Environmental Kuznets curve, Financial Development, Foreign Direct Investment, Urbanization

\title{
INTRODUCTION
}

One of the leading issues receiving global attention from world leaders today, especially in the developed countries, is the issue of climate change and greenhouse gas emissions. The environment is witnessing various forms of pollution such as air, water and land pollution. These can be attributed to the rising population and the accelerated level of industrialization and urbanization. Pollution has resulted in global warming and degradation of the environment. While there are various forms of pollution, the focus of this study shall be on carbon emissions. According to Ozturk and Acaravci (2010), carbon emissions represent about $60 \%$ of the world's total greenhouse gas emission. Some of the reasons for this include the high level of industrialization, high level of energy consumption and increasing economic growth rates. The environmental Kuznet curve hypothesis (EKC) is actually an extension of Kuznets (1955) hypothesis on the relationship between economic growth and income inequality. The EKC hypothesis posits that as the economy develops, at the initial stage, the environment begins to witness pollution and degradation until a turning point is reached whereby, even as the economy continues to grow, there is a decline in the negative impact on the environment. Sri Lanka, which was formerly classified as a lower-middle income country has now been classified as an upper-middle income country (World Bank, 2019). The South Asian country is one of the emerging and developing countries of the region with an annual average growth rate of $4.16 \%$ in the past five years (2015-2019) and a modest inflation rate of $2.1 \%$ in 2018. With such growth rate, it is no surprise that energy consumption has almost doubled from $298 \mathrm{~kg}$ of oil equivalent per capita in 1971 to $516 \mathrm{~kg}$ in 2014 (World Bank WDI, 2019). Also, in 2018, Sri Lanka had a population of 21.6 million, an urban population of $18.5 \%$ of the total population, a Human development index of 0.770 and the Industrial sector contributed $26.1 \%$ of Gross Domestic Product (GDP) (Central Bank of Sri Lanka, 2019).

Tourist arrivals have risen remarkably from 39,654 tourists in 1971 to 1.9 million tourists in 2019 generating gross tourist receipts as at the end of 2019 of \$US 3.6 billion (Sri Lanka Tourism Development Authority, 2019). With such encour-

\footnotetext{
* Corresponding author: Tel.: +234 (81) 333 56400; Email: alabi.mk@unilorin.edu.ng (iD) https://orcid.org/0000-0001-5604-6188
} 
aging macroeconomic statistics and the fact that the industrial sector contributes a quarter of the GDP, it becomes important to find out if an emerging economy like this is growing without huge cost to the environment. This is so because it is known from the theoretical and empirical literature that industrialization leads to increase in economic growth, accompanied by increased energy consumption and this could contribute to a decline in the quality of the environment.

Meanwhile, the country continues to attract foreign direct investment (FDI). From \$US 300,000 in 1971, FDI net inflow rose to \$US 1.6 billion in 2018 but Carbon emissions, CO2, have also risen from 0.29 metric tons per capita in 1971 to 0.89 metric tons per capita in 2014 (World Bank WDI, 2019). With such huge investments coming in and a decrease in the environmental quality, it would be good to know if Sri Lanka has become a pollution haven. The pollution haven hypothesis states that if inward FDI leads to a decline in the quality of the environment of the host country, then such country has become a pollution haven. On the contrary, it is quite possible for the host country not to be a pollution haven provided foreign firms bring in advanced technologies and make use of environmental friendly methods of production.

The objectives of this study are: (1) To test the applicability of the EKC hypothesis to Sri Lanka, (2) To identify the major factors responsible for carbon emissions in the country and (3) To find out if Sri Lanka is a pollution haven.

This study contributes to the knowledge gap in two ways. First, it brings together, in a single study for Sri Lanka, the largest number of explanatory variables known in the literature to contribute to carbon emissions. Such factors include: energy consumption, real per capita GDP, the square of real per capita GDP, urbanization, financial development, tourism and foreign direct investment (FDI). Secondly, it tests the pollution haven hypothesis for Sri Lanka. The findings of this study will help policy makers identify those key factors responsible for environmental degradation and allow them take appropriate steps to address the problem. In addition to that, while the government attracts foreign direct investment, policy makers will be better informed on how best to manage FDI inflow without polluting the environment.

The rest of the paper is as follows: Section 2 gives a brief review of the relevant empirical literature, Section 3 talks about the data and methodology used. In Section 4 results are presented and discussed while Section 5 gives the conclusion and policy implications.

\section{LITERATURE REVIEW AND HYPOTHESIS}

The environmental Kuznet Curve (EKC) hypothesis was postulated based on the perceived relationship between economic growth and the quality of the environment. The EKC hypothesis was named after Simon Kuznet (1955) because of its similarity to Kuznets economic growth-income inequality relationship. The EKC states that at the initial stage of economic growth, the emphasis is on boosting production and income and so very little or no attention is paid to whatever adverse effects such development may have on the environment leading to degradation of the environment. This leads to environmental pollution of all kinds like air, water and soil pollution. What this implies, is that as the economy grows, environmental degradation rises. In the next stage of economic growth, by that time, output and income must have increased, and now, the emphasis is gradually shifting from just mere production and economic growth but towards clean and safe methods of production that are healthy for the environment. It is believed that at that stage, as the economy continues grow, environmental degradation declines due to the use of environmental friendly advanced technology (Shahbaz and Sinha, 2019). In essence, EKC, which captures the economic growth-environmental pollution nexus can be illustrated graphically as an "inverted $U$ curve".

The findings of Grossman and Krueger (1991) paved the way for various studies to come up and assess the relationship between economic growth and environmental degradation. Gross domestic product (GDP) was used as a proxy for economic growth while carbon emission, $\mathrm{CO} 2$, was often used as a proxy for the quality of the environment. Over time, authors began to introduce more explanatory variables into the model such as energy consumption, population, urbanization, institutional factors, trade (exports, imports, trade openness), financial development, tourism and foreign direct investment (FDI). There have been country specific studies and panel studies; studies using time series data and others using panel data; studies that have found the EKC to be valid and others that found no evidence of EKC.

From the literature, it is possible to classify the studies on the economic growth-environmental degradation relationship into five. The first classification of the literature focused mainly on the impact of economic growth (GDP) on environmental pollution (CO2). Some of them include Holtz-Eakin and Selden (1995), Tutulmaz (2015), Fan and Zheng (2013). The second classification of the literature devoted time to studying the impact of energy consumption on environmental pollution. Examples are Cialani (2007), Ahmad et al. (2016). The third classification were studies that investigated the link between energy consumption and economic growth. Such studies include Ho and Siu (2007), Ang (2008), Payne (2009), Zhang and Cheng (2009).

In the fourth classification, authors were interested in understanding the effect of both economic growth and energy consumption on environmental degradation. Examples include Cole, Rayner and Bates (1997), Ang (2007), Saboori, Suleiman and Mohd (2012), Baek (2015), Boluk and Mert (2015), Ozturk and Al-Mulali (2016), Li, Wang and Zhao (2016) Nasreen, Anwar and Ozturk (2017), Alvarez-Herranz, Balsalobre and Cantos (2017).

The fifth classification of the literature focused on introducing more explanatory variables in addition to energy use and economic growth. Such variables include urbanization, trade (or trade openness), financial development, foreign direct investment (FDI) and tourism. For FDI we have Seker, Ertugul and Cetin (2015), Tang and Tan (2015), Alshehry (2015), Pal and Mitra (2017), Zhang, Liu and Bae (2017). For Financial development we have Youssef, Hammoudeh and Omri (2016), Dogan and Turkekul (2016), Nassani et al., (2017) Moghadam and Dehbashi (2017). For Urbanization we have Farhani and Ozturk (2015), Lin et al., (2016), Hao et al., (2016). For tourism we have Qureshi et al., (2017), Katircioglu (2014), Azam, Alam and Hafeez (2018). For Trade we have Halicioglu (2009), Bouznit and Pablo-Romero (2016).

Some studies have used alternative variables to represent environmental pollution instead of the commonly used carbon emission. For instance, Stern (2004) used sulphur rather than carbon emission while Liu et al., (2018) used waste soot and dust, waste water and sulphur dioxide. Al-Mulali et al., (2015), Boutaud, Natacha and Christian, (2006) and CavigliaHarris, Chambers and Khan (2009) used ecological footprint. In other studies, energy consumption was disaggregated into renewable energy consumption and non-renewable energy. Examples include Richmond and Kaufmann (2006), 
Lopez-Menendez, Perez and Moreno (2014), Iwata, Okada and Samreth (2011), Pata (2018).

On the validity of the EKC hypothesis, the following studies have given evidence in support of it. They include: Apergis and Payne (2009), Bilgili, Kocak and Bulut (2016), Apergis and Ozturk (2015), Atici (2009), Gene and Alan (1995), Heidari, Katircioglu and Saeidpour (2015), Ibrahim and Law (2014), Iwata, Okada and Samreth (2012), Nasir and Rehman (2011), Robalino-Lopez et al., (2015), Al-Mulali and Ozturk (2016), Ozatac, Gokmenoglu and Taspinar (2017), Nasreen, Anwar and Ozturk (2017), Pata (2018).

Meanwhile the following studies found no evidence in support of the EKC hypothesis. They are Apergis et al., (2010), Baek and Pride (2014), Begum et al., (2015), Jebli, Youssef and Ozturk (2015), Lantz and Feng (2006), Soytas, Sari and Ewing (2007), Jaforullah and King (2017), Gamage, Kuruppuge and Haq (2017), Gasimli et al., (2019).

The economic growth-energy consumption-environmental degradation relationship has also been analyzed for Sri Lanka by Azam and Khan (2016), Uddin, Bidisha and Ozturk (2016), Gamage, Kuruppuge and Haq (2017), Sriyalatha (2019) and Gasimli et al., (2019). Azam and Khan (2016) investigated the relationship between urbanization and environmental degradation using GDP, energy consumption, total population, urban population and arable land as explanatory variables. From their findings, urbanization contributes to environmental degradation. Uddin, Bidisha and Ozturk (2016) explored granger causality between carbon emission on one hand and energy use, GDP and trade openness on the other. The results indicated that economic growth granger causes carbon emission and economic growth granger causes energy use, with both results being unidirectional.

Gamage, Kuruppuge and Haq (2017) introduced tourism into their model. The explanatory variables used were GDP, the square of GDP, energy consumption and tourism. Based on their results, they concluded that the EKC hypothesis does not hold in Sri Lanka although energy use and tourism contributes to environmental degradation. Similarly, Sriyalatha (2019) while using GDP, trade openness and capital stock, found no evidence to support the EKC hypothesis in Sri Lanka. Finally, Gasimli et al., (2019), included GDP, the square of GDP, energy consumption, urbanization and trade openness in their model. Just like the findings of previous studies, their results gave no evidence in support of the EKC in the country. However, energy consumption, trade openness and urbanization did contribute to carbon emission. From the empirical literature reviewed, it was observed that no study has been conducted yet for Sri Lanka which includes financial development and foreign direct investment among the explanatory variables. Also, the applicability of the pollution haven hypothesis is yet to be tested for Sri Lanka. This study hopes to fill that gap by using as many explanatory variables as identified in the literature such as energy consumption, real per capita GDP, the square of real per capita GDP, urbanization, financial development, tourism and foreign direct investment.

\section{MATERIALS AND METHOD}

Following the model specifications used by Ozatac, Gokmenoglu and Taspinar (2017), Sakiru et al. (2017) and Katircioglu
(2014), this study examined the impact of energy consumption, economic growth (GDP), financial development, urbanization, foreign direct investment (FDI), tourism and trade openness on environmental degradation (represented by carbon emissions $\mathrm{CO} 2$ ). With this model, we are able to test the applicability of the EKC hypothesis to Sri Lanka, identify the major factors causing environmental pollution and assess the validity of the pollution haven hypothesis. The model is given in equation 1 as:

$\mathrm{CO} 2=\mathrm{f}(\mathrm{ENC}, \mathrm{GDP}, \mathrm{GDP} 2, \mathrm{FD}, \mathrm{URB}, \mathrm{FDI}, \mathrm{TRM}$, TO) ..............................(1)

All variables have been converted to their natural logarithm. With this, the model becomes:

$\operatorname{LnCO}_{2 t}=\alpha_{\mathrm{o}}+\beta_{1} \operatorname{LnENC}_{\mathrm{t}}+\beta_{2} \operatorname{LnGDP}_{\mathrm{t}}+\beta_{3} \operatorname{LnGDP}_{\mathrm{t}}^{2}+\beta_{4} \operatorname{LnFD}_{\mathrm{t}}$ $+\beta_{5}$ LnURB $_{t}+\beta_{6}$ LnFDI $_{t}+\beta_{7}$ LnTO $_{t}+\beta_{8}$ LnTRM $_{t}+u_{t} \ldots \ldots \ldots . .(2)$

where $\mathrm{LnCO}_{2 t}$ is Carbon emission measured as metric tons per capita. It was used as a proxy for environmental degradation. $\mathrm{LnENC}_{\mathrm{t}}$ is Energy consumption measured in $\mathrm{kg}$ of oil equivalent per capita, $\operatorname{LnGDP}_{t}$ is real GDP per capita (at constant 2010 US\$), $\operatorname{LnGDP}_{t}{ }^{2}$ is real GDP per capita squared, $\mathrm{LnFD}_{t}$ is financial development, represented by the domestic credit provided to the private sector as a percentage of GDP, LnURB $_{t}$ is Urbanization ratio. It is the ratio of the urban population to the total population, $\mathrm{LnTO}_{t}$ is Trade Openness ratio. It is the ratio of the sum of imports and exports to GDP, LnFDI is Foreign direct investment net inflow as a percentage of GDP, LnTRM is Tourism, represented by the number of tourist arrivals, $u_{t}$ is the error term. Annual data from 19712014 for these variables were obtained from the World Bank World Development Indicator (2019) and the Sri Lanka Tourism Development Annual report (2019).

Descriptive statistics of the data are presented in Table 1 while the correlation analysis is shown in Table 2. The EKC hypothesis can be said to exist in Sri Lanka if $\beta_{2}$, the coefficient of GDP is greater than zero $\left(\beta_{2}>0\right)$ and $\beta_{3}$, the coefficient of GDP2 is less than zero $\left(\beta_{3}<0\right)$. A rise in energy consumption is expected to lead to a rise in carbon emissions and so the coefficient of energy consumption is expected to be positive $\left(\beta_{1}>0\right)$. Similarly, an increased level or urbanization is likely to be associated with an increased carbon emission level and so the coefficient of urbanization ratio is expected to be positive $\left(\beta_{5}>0\right)$. Tourism coefficient is expected to be positive $\left(\beta_{8}>0\right)$. The coefficient for financial development $\left(\beta_{4}\right)$ may be positive or negative, depending on how the domestic credit provided to the private sector is utilized. The private sector may either invest in energy efficient technology and mode of production, and this will help to improve environmental quality or they may just choose any method of production which might be injurious to the environment. For trade openness $\left(\beta_{7}\right)$ and FDI $\left(\beta_{6}\right)$, the coefficients may be positive or negative. This is because trade liberalization attracts not only foreign goods and services but foreign companies may also decide to set up industries in the host country in the form of FDI. If the foreign companies come along with advanced and environmental friendly technology, carbon emissions will reduce, otherwise emissions will go up, especially if the host country government does not mandate foreign companies to use low carbon emitting methods of production and technology. If carbon emissions and all other forms of pollution rise due to increased FDI, then it means the pollution haven hypothesis is applicable to the host country. 
Table1: Descriptive statistics of the variables

\begin{tabular}{|c|c|c|c|c|c|c|}
\hline Variables & Unit & Max & Min & Mean & SD & Obs \\
\hline Carbon emission & Metric tons & 0.8852 & 0.2002 & 0.4036 & 0.1988 & 44 \\
\hline GDP & \$US & 3505.55 & 689.65 & 1570.70 & 788.39 & 44 \\
\hline Energy use & $\mathrm{Kg}$ of oil & 551.02 & 287.01 & 371.72 & 77.34 & 44 \\
\hline Urbanization & Ratio & 18.68 & 17.70 & 18.40 & 0.22 & 44 \\
\hline Financial Dev. & $\%$ of GDP & 35.87 & 8.82 & 23.13 & 8.45 & 44 \\
\hline Trade Openness & Ratio & 0.8864 & 0.4623 & 0.6751 & 0.1166 & 44 \\
\hline Tourism & Tourists & 1527153 & 39654 & 399367 & 295657 & 44 \\
\hline FDI & $\%$ of GDP & 2.85 & 0.000028 & 0.9190 & 0.6290 & 44 \\
\hline
\end{tabular}

Source: Authors computation. 2020. Max stands for maximum, Min stands for minimum and SD stands for standard deviation, $\mathrm{FDI}$ is foreign direct investment and Obs. is number of observations

Results of the correlation matrix are presented in table 2 . It can be observed that there is a positive and statistically significant relationship between carbon emission $\left(\mathrm{CO}_{2}\right)$ on one hand and economic growth, energy consumption, financial development, tourism and FDI on the other. This implies that an increase in the aforementioned variables is associshow a negative but statistically insignificant relationship between $\mathrm{CO}_{2}$ and urbanization and between $\mathrm{CO}_{2}$ and trade openness. Energy consumption had the highest correlation value of 0.9822 with $\mathrm{CO}_{2}$ while trade openness had the least correlation value of 0.1741 with $\mathrm{CO}_{2}$.

ated with an increase in $\mathrm{CO}_{2}$. Meanwhile, the results also

Table 2: Correlation coefficient matrix of the variables

\begin{tabular}{|c|c|c|c|c|c|c|c|c|}
\hline Variables & $\mathrm{CO}_{2}$ & ENG & GDP & URB & FD & TO & TRM & FDI \\
\hline $\mathrm{CO}_{2}$ & 1.0000 & & & & & & & \\
\hline ENG & $0.9822^{*}$ & 1.0000 & & & & & & \\
\hline GDP & $0.9567^{*}$ & $0.9575^{*}$ & 1.0000 & & & & & \\
\hline URB & -0.2637 & -0.2242 & -0.1554 & 1.0000 & & & & \\
\hline FD & $0.8243 *$ & $0.8325^{*}$ & $0.7824^{*}$ & 0.0010 & 1.0000 & & & \\
\hline TO & -0.1741 & -0.1552 & -0.2413 & $0.5586^{*}$ & 0.0940 & 1.0000 & & \\
\hline TRM & $0.8357^{*}$ & $0.7986 *$ & $0.8922 *$ & -0.0223 & $0.6595^{*}$ & -0.1969 & 1.0000 & \\
\hline FDI & $0.5260 *$ & $0.5450 *$ & $0.5387^{*}$ & 0.2785 & $0.5081^{*}$ & $0.3751 *$ & $0.4760 *$ & 1.0000 \\
\hline
\end{tabular}

Source: Authors computation. 2020. CO2 stands for carbon emission, ENG stands for energy consumption, GDP stands for real per capita gross domestic product, URB stands for urbanization, FD stands for financial development, TO stands for trade openness, TRM stands for tourism and FDI is foreign direct investment. ${ }^{*}$ indicates statistical significance at $5 \%$ or less than $5 \%$.

The first step carried out was to test the stationarity of the variables. To do that, the Augmented Dickey-Fuller (ADF) and the Philips-Perron unit root tests were conducted. This study made use of the autoregressive distribute lag (ARDL) Bounds testing approach after performing the unit root tests. This is because it allows the use of variables with both $\mathrm{I}(0)$ and I(1) orders of integration. Also it captures both the short run and long run relationship and the estimators are consistent for short sample size. (Pesaran, Shin and Smith, 2001). The Bounds test was used to detect the presence or absence of cointegration between the variables. If the variables are cointegrated, then an Error Correction Model

(ECM) is specified and estimated. Granger causality test was also conducted to identify the direction of causality among the variables used.

\section{RESULTS AND DISCUSSION}

The Augmented Dickey-Fuller (ADF) and the Philips-Perron unit root tests were carried out. All variables were found to be non-stationary at levels except InURB which was stationary at levels at the one percent statistical significance level. The other variables became stationary after first difference. Results of the unit root test are presented in table 3.

Table 3: Results of the ADF and PP Unit root tests

\begin{tabular}{lrrrr}
\hline & $\begin{array}{c}\text { Augmented } \\
\text { (ADF) Statistic }\end{array}$ & Dickey-Fuller & & Philips-Perron (PP) Statistic \\
\hline At level & Intercept & $\begin{array}{r}\text { Intercept and } \\
\text { trend }\end{array}$ & Intercept & $\begin{array}{r}\text { Intercept and } \\
\text { trend }\end{array}$ \\
\hline LnCO $_{2 t}$ & & -2.010758 & -1.964513 \\
LnENC $_{t}$ & 0.442739 & -2.335055 & 0.461653 & -2.156648 \\
LnGDP $_{t}$ & 0.077841 & -0.708566 & 0.436278 & -0.766806 \\
LnGDP $_{t}{ }_{\text {LnFD }}$ & 3.037986 & -0.233268 & 3.202805 & -0.329833 \\
LnURB $_{t}$ & 3.830158 & -2.708104 & 4.149452 & -2.708104 \\
LnTO $_{t}$ & -1.874891 & $-3.878831^{* *}$ & -1.948155 & $-4.511572^{* * *}$ \\
LnFDI $_{t}$ & $-3.634926 * * *$ & -1.441243 & $-3.081805^{* *}$ & -1.441243 \\
LnTRM $_{t}$ & -1.489881 & $-3.201957^{*}$ & -1.656163 & $-3.210146^{*}$ \\
\hline & -2.703382 & -2.815459 & -2.539928 & -2.780055 \\
\hline
\end{tabular}




\begin{tabular}{lllll}
\hline $\begin{array}{l}\text { At first differ- } \\
\text { ence }\end{array}$ & & & \\
\hline $\mathrm{LnCO}_{2 \mathrm{t}}$ & $-6.343995 * * *$ & $-6.685819 * * *$ & $-6.343995 * * *$ & $-6.683832 * * *$ \\
$\mathrm{LnENC}_{\mathrm{t}}$ & $-7.290149 * * *$ & $-6.520379 * * *$ & $-7.399490 * * *$ & $-7.840491 * * *$ \\
$\mathrm{LnGDP}_{\mathrm{t}}$ & $-5.866910 * * *$ & $-6.445129 * * *$ & $-5.870025 * * *$ & $-6.432670 * * *$ \\
$\mathrm{LnGDP}_{\mathrm{t}}{ }^{2}$ & $-5.226085 * * *$ & $-6.134833 * * *$ & $-5.258065 * * *$ & $-6.144249 * * *$ \\
$\mathrm{LnFD}_{\mathrm{t}}$ & $-6.178845 * * *$ & $-6.100745 * * *$ & $-6.172629 * * *$ & $-6.091839 * * *$ \\
$\mathrm{LnTO}_{\mathrm{t}}$ & $-5.334931 * * *$ & $-5.855068 * * *$ & $-5.367762 * * *$ & $-5.866258 * * *$ \\
$\operatorname{LnFDI}_{\mathrm{t}}$ & $-5.335219 * * *$ & $-5.322904 * * *$ & $-10.67003 * * *$ & $-13.61738 * * *$ \\
LnTRM $_{\mathrm{t}}$ & $-4.242106 * * *$ & $-4.145954 * *$ & $-4.269424 * * *$ & $-4.175420 * *$ \\
\hline
\end{tabular}

Source: Author's computation, 2020. Note: P-values ${ }^{* * *} p<0.01,{ }^{* *} p<0.05,{ }^{*} p<0.1$ : means rejection of the null hypothesis of a unit root at the $1 \%, 5 \%$, and $10 \%$ level respectively. All variables become stationary after taking their first difference except LnURB which is stationary at levels. For the ADF test, Lag lengths were determined automatically using the Schwarz information criterion (SIC). For the PP test, bandwidth was selected automatically using the Newey-West bandwidth.

Given the fact that the variables were a combination of both $I(0)$ and $I(1)$ orders of integration, the next step was to perform a cointegration test using the ARDL Bounds testing approach. This approach is ideal because it allows the use of both $\mathrm{I}(0)$ and $\mathrm{I}(1)$ variables and it also captures the short run and long run equilibrium relationships, including the speed of adjustment. For the autoregressive distributed lag (ARDL) bounds approach, an unrestricted error correction model given in equation (3) was estimated.

$\Delta \mathrm{LnCO}_{2 \mathrm{t}}=\alpha_{0 \mathrm{i}}+\sum_{i=1}^{p} \alpha_{1 \mathrm{i}} \Delta \mathrm{LnCO}_{2 \mathrm{t}-\mathrm{i}}+\sum_{i=0}^{q} \alpha_{2 \mathrm{i}} \Delta \mathrm{LnENG}_{\mathrm{t}-\mathrm{i}}$ $+\sum_{i=0}^{q} \alpha_{3 i} \Delta \mathrm{GDP}_{\mathrm{t}-\mathrm{i}}+\sum_{i=0}^{q} \alpha_{4 i} \Delta \mathrm{LnGDP}_{\mathrm{t}-\mathrm{i}}+\sum_{i=0}^{q} \alpha_{5 i} \Delta \mathrm{FD}_{\mathrm{t}-\mathrm{i}}+$ $\sum_{i=0}^{q} \alpha_{6 i} \Delta$ LnURB $_{\mathrm{t}-\mathrm{i}}+\sum_{i=0}^{q} \alpha_{7 i} \Delta \mathrm{FDI}_{\mathrm{t}-\mathrm{i}}+\sum_{i=0}^{q} \alpha_{8 i} \Delta \mathrm{TO}_{\mathrm{t}-\mathrm{i}}+$ $\sum_{i=0}^{q} \alpha_{9 i} \Delta$ TRM $_{\mathrm{t}-\mathrm{i}}+\beta_{10} \mathrm{LnCO}_{2 \mathrm{t}-\mathrm{i}}+\beta_{11} \mathrm{LnENG}_{\mathrm{t}-\mathrm{i}}+\beta_{12}$ LnGDP $_{\mathrm{t}-\mathrm{i}}+$ $\beta_{13}$ LnGDP $_{\mathrm{t}-\mathrm{i}}+\beta_{14} \mathrm{LnFD}_{\mathrm{t}-\mathrm{i}}+\beta_{15} \mathrm{LnURB}_{\mathrm{t}-\mathrm{i}}+\beta_{16} \mathrm{LnFDI}_{\mathrm{t}-\mathrm{i}}+\beta_{17} \mathrm{LnTO}_{\mathrm{t}-}$ ${ }_{i}+\beta_{18} L_{\text {LnTRM }}{ }_{t-i}+e_{t} \ldots \ldots \ldots \ldots \ldots . . . .$. Equation (3)

The " $q$ " represents the number of lags. The optimal lag length was selected based on the Akaike information criteria (AIC). The null hypothesis for the ARDL-bounds test is that there is no cointegration relationship and this is represented as $\beta_{10}=\beta_{11}=\beta_{12}=\beta_{13}=\beta_{14}=\beta_{15}=\beta_{16}=\beta_{17}=\beta_{18}=0$. The alternative hypothesis is that there is cointegration relationship, represented as $\beta_{10} \neq \beta_{11} \neq \beta_{12} \neq \beta_{13} \neq \beta_{14} \neq \beta_{15} \neq \beta_{16} \neq \beta_{17}$ $\neq \beta_{18} \neq 0$. The computed $F$-value is compared with the upper and lower bounds of the critical value. If the computed $F$ statistic is higher than the upper bound, then the null hypothesis of no cointegration is rejected but if the computed F-statistic is lower than the lower bound, then the null hypothesis is accepted. However, if the F value falls in between the upper and lower bounds of the critical value, then the test is inconclusive (Narayan and Narayan, 2004).

Results showed that Carbon emissions, Energy consumption, real per capita GDP, real per capita GDP squared, Financial Development, Urbanization, FDI, Tourism and Trade Openness are all cointegrated; which means that there is a long-run equilibrium relationship. Since cointegration has been detected, an Error correction model (ECM) was estimated and the results are presented in tables 4 and 5 respectively. The ECM is presented below:

$\Delta \mathrm{LnCO}_{2 \mathrm{t}}=\alpha_{0 \mathrm{i}}+\sum_{i=1}^{p} \alpha_{1 \mathrm{i}} \Delta \mathrm{LnCO}_{2 \mathrm{t}-\mathrm{i}}+\sum_{i=0}^{q} \alpha_{2 \mathrm{i}} \Delta \mathrm{LnENG}_{\mathrm{t}-\mathrm{i}}$ $+\sum_{i=0}^{q} \alpha_{3 i} \Delta \mathrm{GDP}_{\mathrm{t}-\mathrm{i}}+\sum_{i=0}^{q} \alpha_{4 i} \Delta \mathrm{LnGDP}_{\mathrm{t}-\mathrm{i}}+\sum_{i=0}^{q} \alpha_{5 i} \Delta \mathrm{FD}_{\mathrm{t}-\mathrm{i}}+$ $\sum_{i=0}^{q} \alpha_{6 i} \Delta$ LnURB $_{\mathrm{t}-\mathrm{i}}+\sum_{i=0}^{q} \alpha_{7 i} \Delta \mathrm{FDI}_{\mathrm{t}-\mathrm{i}}+\sum_{i=0}^{q} \alpha_{8 i} \Delta \mathrm{TO}_{\mathrm{t}-\mathrm{i}}+$ $\sum_{i=0}^{q} \alpha_{9 i} \Delta \mathrm{TRM}_{\mathrm{t}-\mathrm{i}}+\lambda \mathrm{ECT}_{\mathrm{t}-1}+\mathrm{e}_{\mathrm{t}} \ldots \ldots \ldots \ldots \ldots \ldots . . . . . . .$. Equation (4)
The $\mathrm{ECT}_{\mathrm{t}-1}$ in equation (4) is the error correction term (ECT) while the coefficient of the ECT, $\lambda$, represents the speed of adjustment to the long run equilibrium. Based on the results of the coefficient of the long run estimates, results showed that an increase in energy consumption leads to an increase in carbon emissions. The parameter estimate was statistically significant at the $5 \%$ significance level. A $1 \%$ increase in energy consumption would lead to a $1.29 \%$ rise in carbon emissions in the long run, while holding all other factors constant. Tourism also had the same long-term impact on carbon emissions. The parameter estimate for tourism was 0.376 , it was positive and statistically significant at the $1 \%$ significance level. The interpretation of this is that a $1 \%$ increase in the number of tourist arrivals in Sri Lanka, will lead to a $0.376 \%$ increase in carbon emissions in the long run, while holding other factors constant. These results are in line with a priori expectations. Since it takes some time and a lot of money for all companies to adopt energy-saving and environment friendly methods of production and technology, it is expected that a rise in energy consumption will be associated with a rise in carbon emissions. At the same time, an increase in tourism, is expected to lead to an increase in carbon emissions thereby leading to environmental degradation.

Meanwhile, urbanization ratio which represents the ratio of the urban population to the total population had a negative and statistically significant parameter estimate at the $1 \%$ significance level. A $1 \%$ rise in the urbanization ratio leads to $19.993 \%$ decline in carbon emissions in the long run, while keeping other factors constant. This is contrary to a priori expectations. The most acceptable explanation for this negative relationship between urbanization and carbon emissions is that the government is taking very bold and effective steps in ensuring that all forms of urbanization taking place are based on energy-saving and environment friendly technology, methods of production and construction. This finding is similar to that of Gasimli et al., (2019).

Meanwhile, other explanatory variables such as real GDP, real GDP squared, trade openness, financial development and FDI had statistically insignificant coefficients in the longrun to explain changes in carbon emissions. 
Table 4: Results of the estimation of Long-run coefficients based on the ARDL model

\begin{tabular}{|c|c|c|c|}
\hline \multicolumn{4}{|c|}{ Dependent variable $: \ln \mathrm{CO}_{2}$} \\
\hline Explanatory variable & Coefficient & Standard error & p-value \\
\hline $\operatorname{lnENC}_{t}$ & $1.290^{* *}$ & 0.546 & 0.029 \\
\hline $\operatorname{lnGDP}_{t}$ & 1.216 & 4.839 & 0.804 \\
\hline $\operatorname{lnGDP}_{t}{ }^{2}$ & -0.083 & 0.341 & 0.810 \\
\hline $\operatorname{lnFD_{t}}$ & 0.127 & 0.075 & 0.107 \\
\hline $\operatorname{lnURB}_{t}$ & $-19.993 * * *$ & 5.240 & 0.001 \\
\hline $\operatorname{lnTO} \mathrm{t}_{\mathrm{t}}$ & -0.031 & 0.264 & 0.908 \\
\hline InFDI & 0.014 & 0.014 & 0.335 \\
\hline InTRM & $0.376 * * *$ & 0.126 & 0.008 \\
\hline
\end{tabular}

Source: Author's calculation, 2020. Notes: P-values $* * * p<0.01, * * p<0.05, * p<0.1$ : means variable is statistically significant at the $1 \%, 5 \%$, and $10 \%$ level respectively.

Table 5: Results of the Error Correction Model (ECM) using the ARDL model

\begin{tabular}{|c|c|c|c|}
\hline \multicolumn{4}{|c|}{ Dependent variable $: \ln \mathrm{CO}_{2}$} \\
\hline Explanatory variable & Coefficient & Standard error & $p$-value \\
\hline $\mathrm{ECT}_{\mathrm{t}-1}$ & $-0.574 * * *$ & 0.217 & 0.000 \\
\hline$\Delta \mathrm{ENC}_{\mathrm{t}}$ & 0.547 & 0.540 & 0.324 \\
\hline$\Delta \mathrm{ENC}_{\mathrm{t}-1}$ & $1.164 * *$ & 0.424 & 0.013 \\
\hline$\Delta \mathrm{GDP}_{\mathrm{t}}$ & 26.771 & 21.093 & 0.220 \\
\hline$\Delta \mathrm{GDP}_{\mathrm{t}-1}$ & 23.270 & 15.759 & 0.156 \\
\hline$\Delta G D P^{2}$ & -1.846 & 1.403 & 0.204 \\
\hline$\Delta \mathrm{GDP}^{2} \mathrm{t}-1$ & -1.696 & 1.073 & 0.130 \\
\hline$\Delta \operatorname{lnFD_{t}}$ & 0.053 & 0.083 & 0.525 \\
\hline$\Delta \operatorname{lnFD_{t-1}}$ & $-0.125 *$ & 0.072 & 0.102 \\
\hline$\Delta \ln \operatorname{RBB}_{\mathrm{t}}$ & 3.308 & 21.495 & 0.879 \\
\hline$\Delta \operatorname{lnTO}_{\mathrm{t}}$ & $-0.663 * * *$ & 0.224 & 0.008 \\
\hline$\Delta \operatorname{lnFDI} I_{t}$ & 0.0099 & 0.012 & 0.425 \\
\hline$\left.\Delta \operatorname{lnFDI}\right|_{\mathrm{t}-1}$ & 0.014 & 0.010 & 0.188 \\
\hline$\Delta \operatorname{lnTRM} M_{t}$ & $-0.325 * *$ & 0.135 & 0.026 \\
\hline Constant & $43.025 * *$ & 19.160 & 0.037 \\
\hline
\end{tabular}

Source: Author's calculation, 2020. Notes: P-values $* * * p<0.01,{ }^{* *} p<0.05,{ }^{*} p<0.1$ : means variable is statistically significant at the $1 \%, 5 \%$, and $10 \%$ level respectively.

From the results of the ECM in table 5, the error correction term, $\mathrm{ECT}_{\mathrm{t}-1}$ is -0.574 . It is negative and statistically significant at the $1 \%$ significance level. It means that carbon emissions $\left(\mathrm{CO}_{2}\right)$ converges back to its long-run equilibrium path after any deviations and the speed of adjustment is $57.4 \%$. This further confirms the presence of a long-term equilibrium relationship between $\mathrm{CO}_{2}$ and the other variables. In the short run, carbon emissions rise by $1.164 \%$ when there is a $1 \%$ increase in energy consumption while holding all other factors constant and the coefficient is statistically significant at the $5 \%$ significance level. When financial development increases by $1 \%$ in the short run, carbon emissions decrease by $0.125 \%$ while keeping other factors constant. The coefficient of financial development is statistically significant at the $10 \%$ significance level. Trade openness had a negative and statistically significant coefficient in the short run which was significant at the $1 \%$ significance level. This implies that a $1 \%$ rise in trade openness helps to reduce carbon emissions by $0.663 \%$ while holding all other factors constant. Similarly, a $1 \%$ increase in the number of tourist arrivals, leads to a decrease of $0.325 \%$ in carbon emissions. The coefficient of tourism was negative and statistically significant at the $5 \%$ significance level.

Real per capita GDP and the square of real per capita GDP were both statistically insignificant even though their parameter estimates were both positive. The interpretation of this result is that economic growth is not significant in explaining changes in carbon emissions $\left(\mathrm{CO}_{2}\right)$ and neither is the environmental Kuznets curve hypothesis applicable to Sri Lanka. Other variables such as Urbanization and FDI had statistically insignificant parameter estimates in the short run. With regards to the relevance of the pollution haven hypothesis, this study found no evidence in support of it. This is due to the fact that FDI is insignificant in explaining changes in carbon emission in Sri Lanka. Diagnostic tests were also conducted such as the Durbin Watson test and the Breusch Godfrey test for serial correlation, White test for heteroskedasticity and the cusum test for stability. The results of the diagnostic tests were satisfactory as there was no heteroskedasticity and the model was stable. 
Table 6: Granger causality Wald test

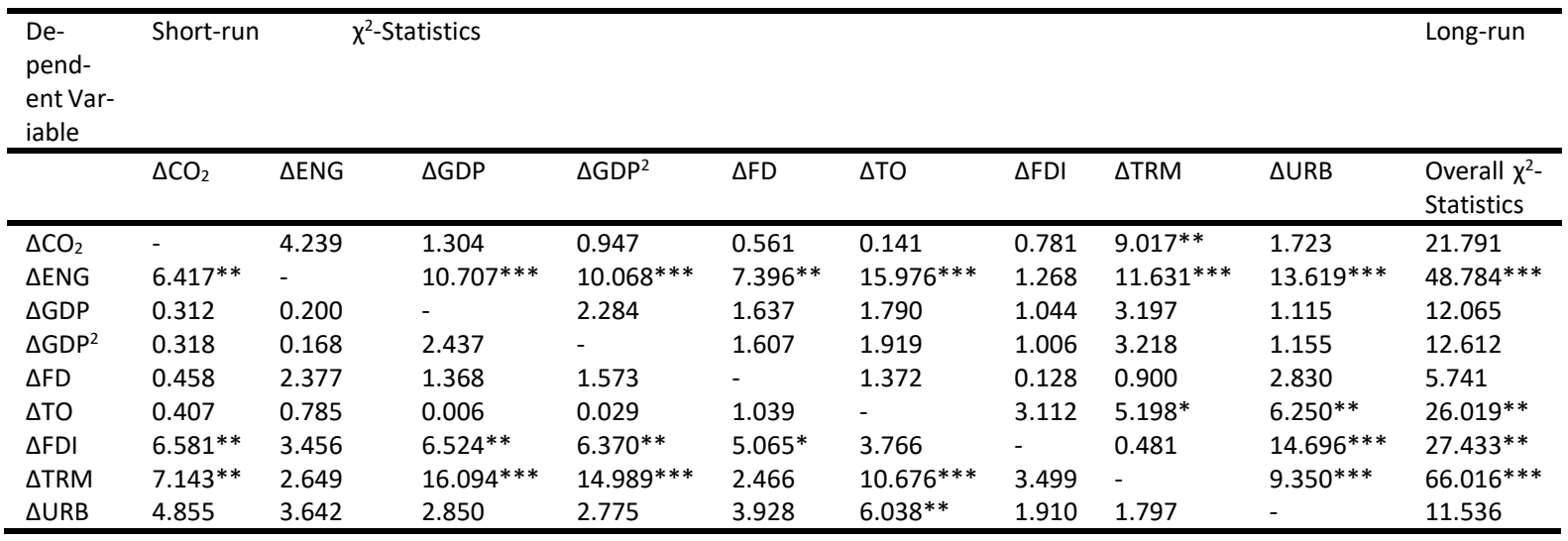

Source: Author's calculation, 2020. Notes: P-values $* * * p<0.01,{ }^{* *} p<0.05,{ }^{*} p<0.1$ : means variable is statistically significant at the $1 \%, 5 \%$, and $10 \%$ level respectively.

Table 6 presents the results of both the short run and long run causality between the variables. In the long run, there is no causality running from energy consumption, GDP, financial development, trade openness, FDI, tourism and urbanization to carbon emissions. This is because the overall chi2 $\left(\chi^{2}\right)$ statistics of 21.791 is statistically insignificant at the $1 \%$,

Table 7: Direction of long run causality

\begin{tabular}{lll}
\hline Explanatory variables granger cause & Explained variable \\
\hline $\mathrm{GDP}, \mathrm{CO}_{2}, \mathrm{FD}, \mathrm{TO}, \mathrm{FDI}, \mathrm{TRM}, \mathrm{URB}$ & $\rightarrow$ & Energy consumption (ENG) \\
$\mathrm{GDP}, \mathrm{ENG}, \mathrm{CO}, \mathrm{FD}, \mathrm{TRM}, \mathrm{FDI}, \mathrm{URB} \rightarrow$ & Trade Openness (TO) \\
$\mathrm{GDP}, \mathrm{ENG}, \mathrm{FD}, \mathrm{CO}_{2}, \mathrm{URB}, \mathrm{TO}, \mathrm{TRM} \rightarrow$ & Foreign Direct Investment (FDI) \\
$\mathrm{GDP}, \mathrm{ENG}, \mathrm{FD}, \mathrm{TO}, \mathrm{FDI}, \mathrm{URB}, \mathrm{CO}_{2} \rightarrow$ & Tourism (TRM) \\
\hline
\end{tabular}

Source: Authors computation, 2020. This arrow $(\rightarrow)$ shows unidirectional long run causality based on the statistical significance of the overall chi2 $(\chi 2)$ statistics.

Table 8: Direction of short-run causality

\begin{tabular}{ll}
\hline Variables & Direction of short run causality \\
\hline GDP $\rightarrow$ ENG & Unidirectional \\
GDP $\rightarrow$ FDI & Unidirectional \\
GDP $\rightarrow$ TRM & Unidirectional \\
$\mathrm{CO}_{2} \rightarrow$ ENG & Unidirectional \\
$\mathrm{CO}_{2} \rightarrow$ FDI & Unidirectional \\
$\mathrm{CO}_{2} \leftrightarrow$ TRM & Bidirectional \\
$\mathrm{FD} \rightarrow$ ENG & Unidirectional \\
$\mathrm{FD} \rightarrow$ FDI & Unidirectional \\
TRM $\rightarrow$ ENG & Unidirectional \\
$\mathrm{URB} \rightarrow$ ENG & Unidirectional \\
URB $\rightarrow$ FDI & Unidirectional \\
URB $\rightarrow$ TRM & Unidirectional \\
TO $\rightarrow$ ENG & Unidirectional \\
TO $\leftrightarrow$ TRM & Bidirectional \\
TO $\leftrightarrow$ URB & Bidirectional \\
\hline
\end{tabular}

Source: Authors computation, 2020. The arrows $(\rightarrow)$ and $(\leftrightarrow)$ show the direction of short run causality based on the statistical significance of the chi2 $(x 2)$ statistics. While $(\rightarrow)$ represents unidirectional, this $(\leftrightarrow)$ represents bidirectional causality.

Table 8 presents the direction of short-run granger causality between the variables. Results showed that tourism granger causes carbon emissions just as carbon emissions granger causes tourism. It means a rise in the number tourist arrivals causes a rise in carbon emissions Also, trade openness has a bidirectional causality with tourism, meaning trade openness causes tourism just as tourism causes trade openness. The direction of causality between trade openness and urbanization is also bidirectional. Economic growth represented by GDP has a unidirectional causality with energy consumption, FDI and tourism running from GDP. It was also observed that urbanization has a unidirectional causality with energy consumption, FDI and tourism. It means higher
$5 \%$ and $10 \%$ significance levels. However, long term unidirectional causality is observed running from GDP, FDI, financial development, trade openness, tourism, $\mathrm{CO}_{2}$ and urbanization to energy consumption due to the overall chi2 $\left(\chi^{2}\right)$ statistics of 48.784 which is statistically significant at the $1 \%$ significance level. The long run causality is illustrated in table 7. 
similar to the findings of Gamage, Kuruppuge and Haq (2017) and Gasimli et al., (2019). It means the relationship between economic growth and carbon emissions does not follow the inverted " $U$ " curve as speculated by the EKC hypothesis. Although economic growth (GDP) had a positive relationship with carbon emission $\left(\mathrm{CO}_{2}\right)$, it was statistically insignificant. The square of GDP, (GDP2) had a negative relationship with $\mathrm{CO}_{2}$ but it was also statistically insignificant.

For the second objective, findings of this study identified the major factors responsible for the quality of the environment in Sri Lanka to be energy consumption, tourism, urbanization, trade openness and financial development. Energy consumption was found to be a key factor both in the short run and in the long run, responsible for the decline in the quality of the environment. Higher energy use resulted in lower quality of the environment. Gamage, Kuruppuge and Haq (2017) and Gasimli et al., (2019) also reported similar result. The policy implication of this is for the government of Sri Lanka to work towards adopting energy saving and environmental friendly technologies and production processes. This can be achieved if government, in conjunction with the private sector, invests heavily into research and development. Also, regulations should be put in place to enforce this. Various incentives can be given to companies and individual that comply with the government initiative to cut down carbon emissions.

Tourism, represented by the number of tourist arrivals, in the short run, had a negative relationship with carbon emissions. The implication of this is that as more tourists arrive into the country, the quality of the environment improves. However, in the long run, the relationship changes to positive, meaning tourism no longer becomes friendly to the environment rather it becomes harmful. More tourist arrivals leads to increased carbon emission. This study recommends that government should study the tourism industry, its players and the tourists with a view to reducing pollution from the industry in the long run. As for urbanization, in the long run, it improves the quality of the environment. This is probably due to increased efficiency in the provision of public utilities. This finding is similar to that of Gasimli et al., (2019). As the country develops and opens up more urban areas, it is imperative for government to make sure that right from the beginning, all technologies and methods of production and construction in these new urban areas are environment friendly.

Trade openness helps to improve the quality of the environment as it has a negative relationship with carbon emissions. This is contrary to the findings of Sriyalatha (2019) who reported that trade causes more damage to the environmental quality. The implication of this finding is that as Sri Lanka opens up to trade, it has put in place measures to ensure that all forms of trade and production coming from outside the country are energy-saving and environment friendly. In addition to that, it means majority of the foreign firms that are into trade with Sri Lanka are already using green technology. Financial development, which was represented by domestic credit provided to the private sector also helped to boost the quality of the environment. With improved financial development, environmental degradation decreased. This is most likely due to the fact that the private sector is gradually beginning to adopt energy-saving and environmental friendly technologies. This study recommends that government should strive to make more domestic credit available and accessible to the private sector.
Lastly, the third objective was to test the applicability of the pollution haven hypothesis in the country. Going by the findings of this study, it can be concluded that the pollution haven hypothesis is not applicable to Sri Lanka. This is because the hypothesis postulates that increased FDI leads to increased pollution for the host country. However, in the case of Sri Lanka, FDI was found not to be a statistically significant variable in explaining the changes in environmental pollution. By extension, it means that at the moment, FDI is not a source of concern to the government with regards to its impact on the quality of the environment. In the meantime, government can begin to implement FDI policies that would ensure that foreign companies bring in and make use of advanced and environmental friendly technologies in their production process. Long run granger causality revealed a unidirectional causality running from GDP, FDI, carbon emissions, urbanization, financial development, trade openness, and tourism to energy consumption. In the short run, bidirectional causality was observed between carbon emissions and tourism; between trade openness and tourism and between trade openness and urbanization. As expected, there was unidirectional causality from GDP to energy use. In conclusion, this study has succeeded in achieving its research objectives.

This study contributes to the knowledge gap in two ways. First, it brings together, in a single study for Sri Lanka, the largest number of explanatory variables known in the literature to contribute to carbon emissions. Such factors include: energy consumption, real per capita GDP, the square of real per capita GDP, urbanization, financial development, tourism and foreign direct investment (FDI). Secondly, it tests the pollution haven hypothesis for Sri Lanka.

\section{REFERENCES}

Ahmad, N., Du, L., Lu, J., Wang, J., Li, H. Z. \& Hashmi, M. Z. (2016). Modelling the

$\mathrm{CO}_{2}$ emissions and Economic growth in Croatia: Is there any Environmental Kuznets Curve? Energy, 123, 164-172.

Al-Mulali, U. \& Ozturk, I. (2016). The investigation of environmental Kuznets curve

hypothesis in the advanced economies: The role of energy prices, Renewable and Sustainable Energy Reviews, 54, 1622-1631.

https://doi.org/10.1016/j.rser.2015.10.131

Al-Mulali, U., Weng-Wai, C., Sheau-Ting, L. \& Mohammed, A. H. (2015)

Investigating the environmental Kuznets curve (EKC) hypothesis by utilizing the ecological footprint as an indicator of environmental degradation, Ecological Indicators, 48, 315-23.

Alshehry, A. S. (2015). Economic Growth and Environmental Degradation in Saudi

Arabia, Journal of Economics and Sustainable Development, 6(2), 3344.

Alvarez-Herranz, A., Balsalobre, D., Cantos, J. M. \& Shahbaz, M. (2017). Energy

Innovations-GHG Emissions Nexus: Fresh Empirical Evidence from OECD Countries, Energy Policy, 101, 90-100.

https://doi.org/10.1016/j.enpol.2016.11.030

Ang, J. B. (2007). $\mathrm{CO}_{2}$ emissions, energy consumption, and output in France, Energy

Policy, 35(10), 4772-4778.

Ang, J. B. (2008). Economic development, pollutant emissions and energy

consumption in Malaysia, Journal of Policy Modeling, 30, 271-278.

Apergis, N. \& Ozturk, I. (2015). Testing environmental Kuznets curve hypothesis in

Asian countries, Ecological Indicators, 52, 16-22. 
Apergis, N. \& Payne J. E. (2009). $\mathrm{CO}_{2}$ emissions, energy usage, and output in Central

America, Energy Policy, 37(8), 3282-3286.

https://doi.org/10.1016/j.enpol.2009.03.048

Apergis, N., Payne, J. E., Menyah, K. \& Wolde-Rufael, Y. (2010). On the causal

dynamics between emissions, nuclear energy, renewable energy, and economic growth, Ecological Economics, 69, 2255-2260.

Atici, C. (2009). Carbon emissions in Central and Eastern Europe: environmental

Kuznets curve and implications for sustainable development, Sustainable Development, 17(3), 155-160.

Azam, M. \& Khan, A. (2016). Urbanization and Environmental Degradation:

Evidence from Four SAARC Countries-Bangladesh, India, Pakistan, and Sri Lanka, Environmental Progress and Sustainable Energy, 35(3), 823 852.

https://doi.org/10.1002/ep

Azam, M., Alam, M. M. \& Hafeez, M. H. (2018). Effect of Tourism on Environmental

Pollution: Further Evidence from Malaysia, Singapore and Thailand, Journal of Cleaner Production, 190, 330-338.

https://doi.org/10.1016/j.jclepro.2018.04.168

Baek, J. (2015). A panel cointegration analysis of $\mathrm{CO}_{2}$ emissions, nuclear energy and

income in major nuclear generating countries, Applied Energy, 145, 133-138.

Baek, J. \& Pride, D. (2014). On the income-nuclear energy- $\mathrm{CO}_{2}$ emissions nexus

revisited, Energy Economics, 43, 6-10.

Begum, R. A., Sohag, K., Abdullah, S. M. S. \& Jaafar M. (2015). CO 2 emissions, energy

consumption, economic and population growth in Malaysia, Renewable and Sustainable Energy Reviews, 41, 594-601.

Bilgili, F., Kocak, E. \& Bulut, U. (2016). The dynamic impact of renewable energy

consumption on $\mathrm{CO} 2$ emissions: A revisited Environmental Kuznets Curve approach, Renewable and Sustainable Energy Reviews, 54, 838-845.

https://doi.org/10.1016/j.rser.2015.10.080

Boluk, G. \& Mert, M. (2015). The renewable energy, growth and environmental

Kuznets curve in Turkey: An ARDL approach, Renewable and Sustainable Energy Reviews, 52, 587-595

https://doi.org/10.1016/j.rser.2015.07.138

Boutaud, A., Natacha, G. \& Christian, B. (2006). Local environmental quality versus

(global) ecological carrying capacity: what might alternative aggregated indicators bring to the debates about Environmental Kunzites curves and sustainable development, International Journal of Sustainable Development, 9(3), 297-310.

https://doi.org/10.1504/ijsd.2006.012850

Bouznit, M. \& Pablo-Romero, M. P. (2016). CO2 emission and economic growth in

Algeria, Energy Policy, 96, 93-104

https://doi.org/10.1016/j.enpol.2016.05.036

Caviglia-Harris, L. J., Chambers, D. \& Kahn, R. J. (2009). Taking the "U" out of

Kuznets: A comprehensive analysis of the EKC and environmental degradation, Ecological Economics, 68, 1149-59.

Central Bank of Sri Lanka (2019). Annual Report

Cialani, C. (2007). Economic growth and environmental quality: An econometric and

a decomposition analysis. Management of Environmental Quality, 18(5), 568-577.

https://doi.org/10.1108/14777830710778328
Cole, M. A., Rayner, A. J. \& Bates, J. M. (1997). The environmental Kuznets curve: an

empirical analysis, Environment and Development Economics, 2(4), 401-416.

Dogan, E. \& Turkekul, B. (2016). $\mathrm{CO}_{2}$ emissions, real output, energy consumption,

trade, urbanization and financial development: Testing the EKC hypothesis for the USA, Environmental Science and Pollution Research, 23(2), 1203-1213.

Fan, C. \& Zheng, X. (2013). An empirical study of the environmental Kuznets curve

in Sichuan Province, China, Environment and Pollution, 2(3), 107-116.

https://doi.org/10.5539/ep.v2n3p107

Farhani, S. \& Ozturk, I. (2015). Causal relationship between $\mathrm{CO}_{2}$ emissions, real GDP,

energy consumption, financial development, trade openness, and urbanization in Tunisia, Environmental Science and Pollution Research, 22(20), 15663-15676.

Gamage, S. K. N., Kuruppuge, R. H. \& Haq, I. (2017). Energy consumption, tourism

development and environmental degradation in Sri Lanka. Energy Sources Part B: Economics, Planning and Policy, 12, 910-916.

Gasimli, O., Haq, I. Gamage S. K. N., Shihadeh, F., Rajapakshe P. S. K. \& Shafiq, M.

(2019). Energy, Trade, Urbanization and Environmental Degradation Nexus in Sri Lanka: Bounds Testing Approach, Energies, 12(1655), 1-

https://doi.org/10.3390/en12091655

Gene, M. G. \& Alan, B. (1995). Economic Growth and the Environment, The

Quarterly Journal of Economics, 110(2), 353-377, [Online] Available from: http://www.jstor.org/stable/2118443 [Accessed: 20th August 2020].

Grossman, G. M. \& Krueger, A. B. (1991). Environmental Impacts of a North

American Free Trade Agreement, Working paper no. w3914, Cambridge: National Bureau of Economic Research.

Halicioglu, F. (2009). An econometric study of $\mathrm{CO}_{2}$ emissions, energy consumption,

income and foreign trade in Turkey, Energy Policy, 37(3), 1156-1164.

http://doi.org/10.1016/j.enpol.2008.11.012

Hao, Y., Chen, H., Wei, Y. M. \& Li, Y. M. (2016). The influence of climate change on

$\mathrm{CO}_{2}$ (carbon dioxide) emissions: An empirical estimation based on Chinese provincial panel data, Journal of Cleaner Production, 131, 667677.

Heidari, H., Katircioglu, S. \& Saeidpour, L. (2015). Economic growth, $\mathrm{CO}_{2}$ emissions,

and energy consumption in the five ASEAN countries, International Journal of Electrical Power and Energy Systems, 64, 785-791.

Ho, C-Y. \& Siu, K. W. (2007). A dynamic equilibrium of electricity consumption and

GDP in Hong Kong: An empirical investigation, Energy Policy, 35(4), 2507-2513.

Holtz-Eakin, D. \& Selden, T. M. (1995). Stoking the fires? $\mathrm{CO}_{2}$ emissions and economic growth, Journal of Public Economics, 57(1), 85-101.

Ibrahim, M. H. \& Law S. H. (2014). Social capital and $\mathrm{CO}_{2}$ emission-output relations:

A panel analysis, Renewable and Sustainable Energy Reviews, 29, 528-534.

Iwata, H., Okada, K. \& Samreth, S. (2011). A note on the environmental Kuznets curve

for $\mathrm{CO}_{2}$ : A pooled mean group approach, Applied Energy, 88(5), 19861996

Iwata, H., Okada, K. \& Samreth, S. (2012). Empirical study on the determinants of 
$\mathrm{CO}_{2}$ emissions: Evidence from OECD countries, Applied Economics, 44, 3513-3519.

Jaforullah, M. \& King, A. (2017). The econometric consequences of an energy

consumption variable in a model of $\mathrm{CO}_{2}$ emissions, Energy Economics, 63, 84-91.

Jebli, M. B., Youssef, M. B. \& Ozturk, I. (2015). The Role of renewable energy

consumption and trade: Environmental Kuznets Curve Analysis for SubSaharan African Countries, African Development Review, 27(3), 288300.

Katircioglu, S. T. (2014). Testing the tourism-induced EKC hypothesis: The case of

Singapore, Economic Modelling, 41, 383-391.

https://doi.org/10.1016/j.econmod.2014.05.028

Kuznets, S. (1955). Economic Growth and Income Inequality. The American

Economic Review, 45(1), 1-28.

Lantz, V. \& Feng, Q. (2006). Assessing income, population, and technology impacts

on $\mathrm{CO}_{2}$ emissions in Canada: Where's the EKC? Ecological Economics, 57(2), 229-238.

Li, T., Wang, Y. \& Zhao, D. (2016). Environmental Kuznets Curve in China: New

Evidence from Dynamic Panel Analysis, Energy Policy, 91, 138-147.

Lin, B., Omoju, O. E., Nwakeze, N. M., Okonkwo, J. U. \& Megbowon, E. T. (2016). Is

the environmental Kuznets curve hypothesis a sound basis for environmental policy in Africa? Journal of Cleaner Production, 133, 712-724.

Liu, Q., Wang, S., Zhang, W., Zhan, D. \& Li, J. (2018). Does foreign direct investment

affect environmental pollution in China's cities? A spatial econometric perspective, Science of the Total Environment, 613, 521-529.

Liu, X. \& Bae, J. (2018). Urbanization and industrialization impact of $\mathrm{CO} 2$ emissions

in China, Journal of Cleaner Production, 172, 178-186.

https://doi.org/10.1016/j.jclepro.2017.10.156

Lopez-Menendez, A. J., Perez, R. \& Moreno, B. (2014). Environmental costs and

renewable energy: Re-visiting the Environmental Kuznets Curve, Journa of Environmental Management, 145, 368-373.

https://doi.org/10.1016/j.jenvman.2014.07.017

Moghadam, H. E. \& Dehbashi, V. (2017). The impact of financial development and

trade on environmental quality in Iran. Empirical Economics, 54(4), 1777 1799.

Narayan, P. K. \& Narayan, S. (2004). The J-curve: Evidence from Fiji, International

Journal of Applied Economics, 18, 369-380.

Nasir, M. \& Rehman F. U. (2011). Environmental Kuznets Curve for carbon emissions

in Pakistan: an empirical investigation, Energy Policy, 39(3), 18571864.

https://doi.org/10.1016/j.enpol.2011.01.025

Nasreen, S., Anwar, S. \& Ozturk, I. (2017). Financial stability, energy consumption

and environmental quality: Evidence from South Asian economies, $R e-$ newable and Sustainable Energy Reviews, 67, 1105-1122.

Nassani, A. A., Aldakhil, A. M., Abro, Q. M. \& Zaman, K. (2017). Environmental

Kuznets curve among BRICS countries: Spot lightening finance, transport, energy and growth factors, Journal of Cleaner Production, 154, 474-487.

http://doi.org/10.1016/j.jclepro.2017.04.025

Ozatac, N., Gokmenoglu, K. K. \& Taspinar, N. (2017). Testing the EKC hypothesis by considering trade openness, urbanization, and financial development: The case of Turkey, Environmental Science and Pollution Research, 24(20), 16690-16701.

https://doi.org/10.1007/s11356-017-9317-6

Ozturk, I. \& Acaravci, A. (2010). $\mathrm{CO}_{2}$ Emissions, Energy Consumption and Economic

Growth in Turkey, Renewable and Sustainable Energy Reviews, 14, 32203225.

Pal, D. \& Mitra, S. K. (2017). The environmental Kuznets curve for carbon dioxide in

India and China: Growth and pollution at crossroad, Journal of Policy Modeling, 39(2), 371-385.

Pata, U. K. (2018). Renewable Energy Consumption, Urbanization, Financial

Development, Income and $\mathrm{CO}_{2}$ Emissions in Turkey: Testing EKC Hypothesis with Structural Breaks, Journal of Cleaner Production, 187, 770779

https://doi.org/10.1016/j.jclepro.2018.03.236

Payne, J. E. (2009). On the dynamics of energy consumption and output in the US,

Applied Energy, 86(4), 575-577.

Pesaran, M. H., Shin, Y. \& Smith, R. (2001). Bounds testing approaches to the analysis

of level relationships, Journal of Applied Econometrics, 16(3), 289326.

https://doi.org/10.1002/jae.616

Qureshi, M. I., Hassan, M. A., Hishan, S. S., Rasli, A. M. \& Zaman, K. (2017). Dynamic

linkages between sustainable tourism, energy, health and wealth: Evidence from top 80 international tourist destination cities in 37 countries, Journal of Cleaner Production, 158, 143-155.

Robalino-Lopez, A., Mena-Nieto, A., Garcia-Ramos, J-E. \& Golpe, A. A. (2015).

Studying the relationship between economic growth, $\mathrm{CO}_{2}$ emissions, and the environmental Kuznets curve in Venezuela (1980-2025), Renewable and Sustainable Energy Reviews, 41, 602-614.

Richmond, A. K. \& Kaufmann, R. K. (2006). Is there a turning point in the relationship between income and energy use and/or carbon emissions? Ecological Economics, 56(2), 176-189.

Saboori, B., Sulaiman, J. B. \& Mohd, S. (2012). An Empirical Analysis of the

Environmental Kuznets Curve for $\mathrm{CO}_{2}$ Emissions in Indonesia: The Role of Energy Consumption and Foreign Trade, International Journal of Economics and Finance, 4(2), 243-251.

Seker, F., Ertugul, H. M. \& Cetin, M. (2015). The impact of foreign direct investment

on environmental quality: A bounds testing and causality analysis for Turkey, Renewable and Sustainable Energy Reviews, 52, 347-356.

https://doi.org/10.1016/j.rser.2015.07.118

Shahbaz, M. \& Sinha, A. (2019). Environmental Kuznets curve for $\mathrm{CO}_{2}$ emissions: A literature survey, Journal of Economic Studies, 46(1), 106-168.

https://doi.org/10.1108/JES-09-2017-0249

Solarin, S. A., Al-Mulali, U., Musah, I, \& Ozturk, I. (2017). Investigating the Pollution

Haven Hypothesis in Ghana: An Empirical Investigation, Energy, 124, 706-719.

https://doi.org/10.1016/j.energy.2017.02.089

Soytas, U., Sari, R. \& Ewing, B. T. (2007). Energy consumption, income, and carbon

emissions in the United States, Ecological Economics, 62(3), 482-489.

Sri Lanka Tourism Development Authority (2019). Annual report for 2019.

Sriyalatha, M. A. K. (2019). An empirical study of the relationships between $\mathrm{CO}_{2}$

emissions, trade openness and economic growth in south Asian countries, Sri Lankan Journal of Business Economics, 8(1), 24-45. 
Stern, D. I. (2004). The rise and fall of the environmental Kuznets curve, World

Development, 32(8), 1419-1439.

Tang, C. F. \& Tan, B. W. (2015). The impact of energy consumption, income and

foreign direct investment on carbon dioxide emissions in Vietnam, Energy, 79, 447-454.

Tutulmaz, O. (2015). Environmental Kuznets curve time series application for

Turkey: Why controversial results exist for similar modes? Renewable and Sustainable Energy Reviews, 50, 73-81.

Uddin, G. S., Bidisha, S. H. \& Ozturk, I. (2016). Carbon Emissions, Energy

Consumption, and Economic Growth Relationship in Sri Lanka, Energy Sources, Part B: Economics, Planning and Policy, 11(3), 282-287.

https://doi.org/10.1080/15567249.2012.694577

Youssef, A. B., Hammoudeh, S. \& Omri, A. (2016). Simultaneity modeling analysis of

the environmental Kuznets curve hypothesis, Energy Economics, 60 266-274.

Zhang, S., Liu, X. \& Bae, J. (2017). Does trade openness affect $\mathrm{CO}_{2}$ emissions:

evidence from ten newly industrialized countries? Environmental Science and Pollution Research, 24, 17616-17625.

Zhang, X-P. \& Cheng, X-M. (2009). Energy consumption, carbon emissions, and

economic growth in China, Ecological Economics, 68(10), 2706-2712.

World Bank (2019). World Development Indicators [Online] Available from:

http://data.worldbank.org/data-catalog/world-development-indicators (Accessed 20th August 2020). 
